\title{
Raceme and fruit position in the chemical composition of castor beans during storage
}

\section{Posição do racemo e fruto na composição química de grãos de mamona durante o armazenamento}

\author{
Carla Gomes MACHADO'; Cibele Chalita MARTINS ${ }^{2}$; Gabriela Fernandes GAMA ${ }^{3}$; \\ Givanildo Zildo da SILVA ${ }^{4}$; Amalia Andreza Sousa SILVA ${ }^{3}$; Simério Carlos Silva CRUZ ${ }^{1}$
}

1 Engenheiros Agrônomos, Professores, Doutores, Universidade Federal de Jataí - UFG, Programa de Pós-Graduação em
Agronomia, Jataí, GO, Brasil. carlagomesmachado@gmail.com; simerio@ufg.br
${ }^{2}$ Engenheira Agrônoma, Professora Livre-Docente, Faculdade de Ciências Agrárias e Veterinárias - UNESP, Jaboticabal, SP,
Brasil. cibele.chalita@unesp.br
${ }^{3}$ Engenheira Agrônomas, Mestrandas, Universidade Federal de Jataí - UFG, Programa de Pós-Graduação em Agronomia,
Jataí, GO, Brasil. gabifgama@hotmail.com; amaliaandreza@hotmail.com
${ }^{4}$ Autor para correspondência. Engenheiro Agrônomo, Professor, Universidade Federal de Jataí - UFG, Programa de Pós-
Graduação em Agronomia, Jataí, GO, Brasil. givanildozildo@gmail.com

Recebido em: 11-06-2020; Aceito em: 25-08-2020

\begin{abstract}
This study evaluates the influence of the raceme position in the plant, the fruit position in the raceme, and the storage period on the chemical composition of castor beans. The experiment was initially performed in field, where planting and monitoring was performed according to crop requirements. After harvesting the first three racemes, the following treatments were evaluated in a completely randomized design with subdivided plots: raceme position in the plant, fruit position in the raceme, and storage. In laboratory, the contents of water, protein, oil, and ash were determined, being submitted to $\mathrm{F}$ test and compared by Tukey test when significant. The raceme position in the plant and the fruit position in the raceme do not interfere with the chemical composition of castor beans. During storage, the oil content is viable up to a maximum of eight months. Protein content was maintained high in tertiary racemes until the twelfth month.
\end{abstract}

Additional keywords: Al Guarany 2002; oil content; post-harvest; protein content; Ricinus communis.

\begin{abstract}
Resumo
Objetivou-se avaliar a influência da posição do racemo na planta, do fruto no racemo e do período de armazenamento na composição química dos grãos de mamona. O experimento foi conduzido inicialmente em campo, sendo realizado o plantio e acompanhamento conforme exigências da cultura e a colheita dos três primeiros racemos, onde foram avaliados os seguintes tratamentos: posição do racemo na planta, posição do fruto no racemo e armazenamento. Em delineamento inteiramente casualizado, com parcelas subsubdivididas. No laboratório foram determinados os teores de água, proteína, óleo e cinzas, sendo esses submetidos ao teste $\mathrm{F}$ e quando significativos comparados pelo teste de Tukey. A posição do racemo na planta e do fruto no racemo não interferem na composição química dos grãos de mamona. Durante o armazenamento, o teor de óleo é viável no máximo até o $8^{0}$ mês. O teor de proteína, se mantem alto nos racemos terciários, até o $12^{0}$ mês.
\end{abstract}

Palavras-chave adicionais: Al Guarany 2002; pós-colheita; Ricinus communis; teor de óleo; teor de proteína

\section{Introduction}

Castor bean (Ricinus communis L.) production has increased considerably due to the high quality of its oil and for being the raw material for biodiesel production, with government support in Brazil through the Family Farming and Price Guarantee Program - PGPAF (CONAB, 2019). Thus, it has become a good alternative for family farmers, encouraging biodiesel production, compared to other options that demand high technology for production, such as soybeans, peanuts, and sunflowers.

Castor bean is a perennial plant with different growth habits, having prolonged flowering and fertiliza- tion. Thus, each raceme, fruit or grain can be formed under different edaphoclimatic conditions. Each plant produces several racemes and fruits within each raceme that ripen sequentially and unevenly (Foloni et al., 2011). Therefore, grains harvested in different racemes or positions in the raceme are affected by the environmental conditions before and during their formation, and may present different size, weight, and chemical composition. These characteristics can influence the initial quality of the grains and their storage potential (Queiroga et al., 2012; Fogaça et al., 2017; Zuchi et al., 2010).

Indehiscent cultivars are used in most of the area planted with castor bean in the State of São Paulo, 
Brazil, especially the Al Guarany 2002, developed by the Department of Seeds, Seedlings, and Matrices (DSMM) of the Integral Technical Assistance Coordination/Integral Technical Assistance Coordination. This cultivar has a mean yield of 1,000 to $2,500 \mathrm{~kg} / \mathrm{ha}$; 180-day cycle, which is relatively short; medium size (from 1.60 to $2.60 \mathrm{~m}$ ), facilitating harvest; drought resistance, and seed oil content from 43 to $49 \%$ (MAPA, 2019).

For indehiscent cultivars, fruit harvest is performed in a single step when racemes are dry, mechanically, especially if aimed at oil extraction (Chechetto et al., 2010; Soratto et al., 2011). However, most cultivars lack ripening uniformity, a fact stated by Zuchi et al. (2010). The data obtained by the authors demonstrate variation in the ripening of cultivars IAC 226, Al Guarany 2002, BRS 188, and IAC 80 according to sowing times. However, there is lack of studies on the difference of ripening between racemes and between fruits in the raceme. Thus, this study evaluates the influence of the raceme position in the plant, fruits position in the raceme, and the storage period on the chemical composition of castor beans of cultivar $\mathrm{Al}$ Guarany 2002.

\section{Material and methods}

The experiment was performed at the School of Agronomic Sciences, Universidade Estadual Paulista, Botucatu campus, São Paulo State, Brazil (2249'31" S latitude and $48^{\circ} 25^{\prime} 37^{\prime \prime} \mathrm{W}$ longitude, altitude of $770 \mathrm{~m}$ ). The climate corresponds to the Köppen climate classification category Cwa, humid tropical, with dry winters (June to August) and rainy summers (December to February). The experiment consisted of two stages, initially in field and later in laboratory.

\section{Field stage}

For sowing, a uniform area of $1638 \mathrm{~m}^{2}$ was selected. Conventional tillage was used for preparation, consisting of two harrows and one plowing.

Sowing with the cultivar AL Guarany 2002 was performed with spacing of $1.80 \mathrm{~m}$ between rows and population of one plant per meter. Sowing fertilization was performed according to the results obtained in the soil analysis, sampled before the area was prepared. For chemical fertilization, $12 \mathrm{~g}, 30 \mathrm{~g}$, and $12 \mathrm{~g}$ of $\mathrm{N}, \mathrm{P}_{2} \mathrm{O}_{5}$, and $\mathrm{K}_{2} \mathrm{O}$, respectively, were applied per linear meter in the formula (4-14-8), corresponding to the dose of 120$-300-240 \mathrm{~kg} \mathrm{ha}{ }^{-1}$, applied and incorporated along the line.

All phytosanitary treatments necessary for the good development of plants were performed during cultivation. Weeding was performed manually.

At harvest, the first three racemes were cut, collected, and transported to a covered shed until evaluation of the following treatments:

Raceme position in the plant: Racemes were separated according to their position in the plant, characterized as primary, secondary, and tertiary, respec- tively, which were the first, second, and third racemes grown by plants.

Fruit position in the raceme: Each raceme was measured from the insertion point of the first fruit to the insertion point of the last fruit using a measuring tape. Racemes were then divided into three length segments, the upper third, middle third, and lower third treatments.

Storage: After harvesting the three racemes and subdividing them into three thirds, the grains were manually extracted and cleaned, removing empty grains and impurities. The grains were separated into subsamples and stored in Kraft paper bags for twelve months in the laboratory, with average temperature of $25.6 \pm 2.3 \stackrel{\circ}{\circ}$ and relative humidity of $40.0 \pm 10.0 \%$, registered by thermohygrograph. The chemical composition of grains was evaluated at zero, three, six, and twelve months of storage.

The completely randomized experimental design was used to evaluate the chemical composition of the grains, using subdivided plots with four or eight subsamples depending on the evaluation. The raceme position in the plant was evaluated in the plot; the fruit position in the raceme in the subplot; and the storage periods in the subsubplot.

\section{Laboratory stage}

This stage was performed in the laboratory for seed analysis of the Universidade Estadual Paulista Júlio de Mesquita Filho, School of Agronomic Sciences, Botucatu Campus, Department of Plant Production, where characterization, conditioning, and determination of the chemical composition of grains was performed.

Water content (\%) was determined by oven method at $105 \pm 3 \stackrel{\circ}{\circ}$ for 24 hours, with four samples of five seeds per repetition for each treatment (Brasil, 2009).

The chemical composition of the grains was evaluated as follows:

Protein content: Determined from the nitrogen content of the samples with eight subsamples of grains, using the semi-micro Kjeldahl method (Malavolta et al., 1989).

Oil content: Determined with four subsamples of twenty grains macerated in a mortar and dried inside cartridges in a forced air circulation oven at $60^{\circ} \mathrm{C}$ for six hours. Samples were weighed and subjected to extraction with $650 \mathrm{~mL}$ of hexane for seven hours in an extractor with capacity of nine samples. Samples were dried again for six hours and weighed. Oil content was determined by the formula established by Soxhlet and adapted by Myczkowski (2003).

Ash content: Determined with eight subsamples of grains macerated in a mortar. Each sample was weighed and placed in a porcelain capsule in a muffle furnace at $550^{\circ} \mathrm{C}$ for six hours, transferred to a desiccator for thirty minutes and weighed. The percentage of ash was calculated using the formula by Lara et al. (1985).

All variables were subjected to $F$ test and means were compared by Tukey test at $5 \%$ probability when significant. 


\section{Results and discussion}

For oil and water content, only the storage period was significant. For protein content, only the interaction between raceme position in the plant and storage period was significant. As for ash content, only the storage period was significant. However, the interaction of the three factors, raceme position in the plant, fruit position in the raceme, and storage period were significant for ash content (Table 1).

Table 1 - Analysis of variance for oil, protein, ash and water content as function of grains from different positions of the racemes in the plant and fruits in the raceme, stored for five periods.

\begin{tabular}{|c|c|c|c|c|c|}
\hline \multirow{2}{*}{ Sources of Variation } & \multirow{2}{*}{ FD } & \multicolumn{4}{|c|}{ Content } \\
\hline & & Oil & Protein & Ash & Water \\
\hline Plot - raceme position in the plant $(\mathrm{RP})$ & 2 & $8.44^{\mathrm{ns}}$ & $8.13^{\mathrm{ns}}$ & $0.21^{\mathrm{ns}}$ & $0.01^{\mathrm{ns}}$ \\
\hline Plot residue & 9 & 4.90 & 3.67 & 0.14 & 0.53 \\
\hline Plots & 11 & - & - & - & - \\
\hline Coefficient of Variation of the Plot (\%) & - & 4.64 & 11.17 & 10.89 & 5.66 \\
\hline Subplot - Fruit position in the raceme (FP) & 2 & $2.03^{n s}$ & $0.29^{\mathrm{ns}}$ & $0.02^{\mathrm{ns}}$ & $4.11^{\mathrm{ns}}$ \\
\hline $\mathrm{RP} \times \mathrm{FP}$ & 4 & $4.64^{\mathrm{ns}}$ & $2.64^{\mathrm{ns}}$ & $0.06^{\mathrm{ns}}$ & $0.23^{\mathrm{ns}}$ \\
\hline Subplot residue & 18 & 1.85 & 1.30 & 0.12 & 1.38 \\
\hline Subplots & 35 & - & - & - & \\
\hline Coefficient of Variation of the Subplot (\%) & - & 2.86 & 6.65 & 9.99 & 9.14 \\
\hline Subsubplot - Storage period (SP) & 3 & $45.31^{* \star}$ & $1.89 \mathrm{~ns}$ & $0.60^{* *}$ & $3.33^{\star \star}$ \\
\hline $\mathrm{RP} \times \mathrm{SP}$ & 6 & $1.78^{\mathrm{ns}}$ & 4.90 & $0.10^{\text {ns }}$ & $0.19^{n s}$ \\
\hline $\mathrm{FP} \times \mathrm{SP}$ & 6 & $1.82^{\mathrm{ns}}$ & $2.86^{\mathrm{ns}}$ & $0.04^{\mathrm{ns}}$ & $0.75^{\mathrm{ns}}$ \\
\hline$R P \times F P \times S P$ & 12 & $1.98^{\mathrm{ns}}$ & $2.31^{\mathrm{ns}}$ & $0.26^{*}$ & $0.67^{\mathrm{ns}}$ \\
\hline SubPlot residue & 81 & 1.67 & 2.12 & 0.14 & 0.73 \\
\hline Total & 143 & & - & - & \\
\hline Coefficient of Variation of the Subsubplot ( & - & 2.71 & 8.49 & 10.86 & 6.66 \\
\hline
\end{tabular}

${ }^{n s}=$ Not significant by the $F$ test $(p>0.05),{ }^{*}$ and ${ }^{* *}=$ Signficant by the $F$ test to 5 and $1 \%$ of probability, respectively, $\mathrm{FD}=$ Freedom degree.

The oil content of the grains varied during storage periods, with the largest accumulation of $48.69 \%$ verified at the eighth month, compared to all other periods (Figure 1). Similar results were found by Perdomo et al. (2013), who compared seven castor bean cultivars and obtained a mean of $48.80 \%$ oil accumulation. Jatropha curcas also increased oil content in approximately $20 \%$ until the fourth month of storage (Furquim, 2014), which is interesting, as its oil is a product of interest to the industry, making storage a good option for increased yield.



Figure 1 - Oil, ash and water contents from castor beans during storage. 
The ash content in grains is commonly used for nutritional evaluation, and studies are necessary to identify and classify nutrients and mineral elements in the sample. Thus, ash content was evaluated only for storage periods in this study (Figure 1). Linear decrease was observed during storage periods due to the natural process of grain deterioration after harvest (Figueiredo et al., 2017, Rocha et al., 2017). Concomitantly, the water content of grains increased linearly during storage periods, which is explained by seed hygroscopicity, the permeable packaging (Kraft paper), and the storage location, an uncontrolled environment.

In the periods of zero, three, and six months, there was no statistical difference in relation to protein content in the three racemes analyzed. At twelve months of storage, the tertiary raceme obtained the largest means without differing, in turn, from the primary raceme, which also not differed from the secondary raceme (Figure 2).

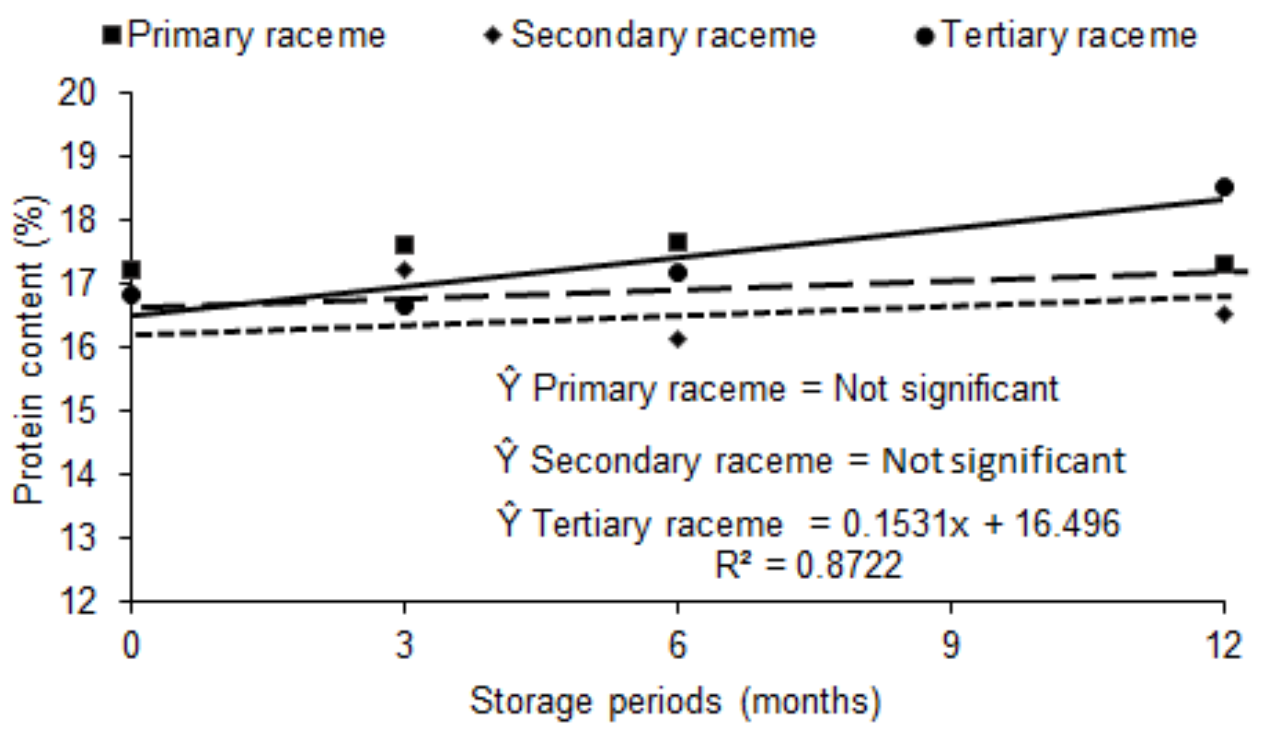

Figure 2 - Comparison of means of the interaction between raceme position in the plant and storage periods in relation to the protein content of castor beans.

Soon after harvest, differences in protein content were not observed in the grains of the racemes evaluated. However, they behaved linearly, with a marked increase for grains of the tertiary raceme during storage periods, which maintained high protein content until the twelfth month, becoming an alternative for use in animal feed, even after storage. We could infer that this increase is linked to decreasing oil, since their contents are inversely proportional (Daronch et al., 2018). However, there was no effect of the storage factor on protein and there was no difference between oil content in the thirds of the raceme. Therefore, further studies are needed to explain this fact physiologically.

It should also be noted that, in castor bean, racemes do not develop at the same time in the plant. Thus, racemes, fruits, and seeds can be harvested in several stages, as to minimize the effects of uneven ripening and maximize seed quality (Foloni et al., 2011). Difference in protein content during storage periods can be attributed to the harvest in this research, which was performed in a single moment, possibly with different degrees of ripening and uniformity between racemes.

\section{Conclusion}

The raceme position in the plant and the fruit position in the raceme do not interfere with the chemical composition of castor beans. During storage, the oil content is viable up to a maximum of eight months. Protein content was maintained high in tertiary racemes until the twelfth month.

\section{Acknowledgments}

To the Coordination for the Improvement of Higher Education Personnel (CAPES) for granting financial support to the research and to the ad hoc reviewers of this article for the valuable suggestions and corrections.

\section{References}

Brasil (2009) Ministério da Agricultura, Pecuária e Abastecimento. Regras para análise de sementes / Ministério da Agricultura, Pecuária e Abastecimento. Secretaria de Defesa Agropecuária. - Brasília: Mapa/ACS, 399p. 
Chechetto RG, Siqueira R, Gamero CA (2010) Balanço energético para a produção de biodiesel pela cultura da mamona (Ricinus communis L.). Revista Ciência Agronômica 41:546-553.

CONAB (2019) Companhia Nacional de Abastecimento. Indicadores da Agropecuária. Brasília: Conab. Disponível em: https://www.conab.gov.br/infoagro/precos/revista-indicadores-da-agropecuaria. Acessado em 09.12.2019.

Daronch DJ, Peluzio JM, Afferri FS, Tavares AT, Souza CM (2018). Chemical composition of grains and environmental efficiency in soybeans grown under low latitude conditions. Científica 46:359-366.

Figueiredo JC, David AMS de S, Silva C da D, Amaro HTR, Alves DD (2017) Maturação de sementes de pimenta em função de épocas de colheita dos frutos. Scientia Agraria 18:1-7.

Fogaça JJN, Silva RA, Santos JL, Nunes TC, Ferreira LL, Morais OM (2017) Qualidade fisiológica de sementes de mamona crioula var: Carrapatinho em função da posição do rácemo. Revista de Ciências Agrárias 40:87-93.

Foloni JSS, Hirata ACS, Pereira DN, Carvalho MLM de, Casavechia D (2011) Dessecação química em précolheita da mamona. Revista Ceres 58:665-669.

Furquim LC, Castro CF de S, Resende O, Campos JMC, Cabral AL, Furquim Filho CS (2014) Efeito da secagem e do armazenamento das sementes de pinhão-manso (Jatropha curcas L.) na qualidade do óleo. Científica-Multidisciplinary Journal 1:51-70.

Lara ABWH, Nazario G, Pregnolato W (1985) Normas analíticas do Instituto Adolfo Lutz: métodos químicos e físicos para análise de alimentos. 3. ed. São Paulo: Instituto Adolfo Lutz 1:302-30.
Malavolta E, Vitti GC, Oliveira SA (1989) Avaliação do estado nutricional das plantas: princípios e aplicações. Piracicaba: POTAFOS. 319p.

MAPA (2019) Ministério da Agricultura, Pecuária e Abastecimento. 2019. Portaria $n^{\circ} 230$, de 22 de Agosto de 2019. Brasília.

Myczkowski ML (2003) Variabilidade genética para o teor de óleo entre progênies autofecundadas de mamona (Ricinus communis L.) da cultivar Guarani. Dissertação 33 f., Universidade Estadual Paulista Júlio de Mesquita Filho, Botucatu.

Perdomo FA, Acosta OAA, Herrera G, Leal VJF, Mosquera AJD, Malo MB, Garcia RME (2013) Physicochemical characterization of seven Mexican Ricinus communis L. seeds \& oil contents. Biomass and Bioenergy 48:17-24.

Queiroga V de P, Borba FG, Almeida KV de, Sousa WJB de, Queiroga DAN (2012) Influência da ordem dos racemos na planta e sistemas de beneficiamento na qualidade de sementes de mamona. Revista Agro@mbiente On-line 6:40-46.

Rocha GC, Rubio Neto A, Cruz SJS, Campos GWB, Castro AC de O, Simon GA (2017) Qualidade fisiológica de sementes de soja tratadas e armazenadas. Científica-Multidisciplinary Journal 4:50-65.

Soratto RP, Schlick GD de S, Giacomo BMS, Zanotto MD, Fernandes AM (2011) Espaçamento e população de plantas de mamoneira de porte baixo para colheita mecanizada. Pesquisa Agropecuária Brasileira 46: 245-253.

Zuchi J, Bevilaqua GAP, Sediyama CS, Zanuncio JC (2010) Variações na qualidade e tamanho de sementes de mamona pela época de semeadura e ordem floral. Revista Ciência Agronômica 41:403-408. 